\title{
BODILY INJURY BY FAULT IN THE NEW ROMANIAN CRIMINAL CODE
}

\author{
Bela Attila Zazula, PhD student \\ University of Science Academy in Moldova
}

(Received January 2016; Accepted March 2016)

\begin{abstract}
In all constitutional systems, there is a reticence in sanctioning criminally any injury caused by fault to a person, without taking into account certain aspects really justifying the penology's intervention - a severe injury of the victim's body, a case where there are broken prudence norms enacted precisely for avoiding the bodily injury by fault of a person.
\end{abstract}

Key words: fault, severe bodily injury

\section{Introduction}

These infractions present a high generic level of social danger determined, on one hand, by the importance of social values making the object of criminal protection and the serious consequences that these infractions can have on the community, and on the other hand, by the fact that the infractions against that person are usually done by using violent means or procedures and have a higher frequency in relation to other categories of infractions.

\section{Overall considerations}

The infraction of bodily injury by fault represents an antisocial manifestation, being carried out through a manifestation that brings damages to social relationships.

It belongs to the group of infractions against the body or health.

The body and the life itself are protected by law not only against the deeds committed intentionally, but also the ones committed by fault. In other words, it is imperative for the protection of the person's body and health to be done against unintentional deeds.

The infraction of bodily injury mentioned at art. 196 in the Criminal code have at its base two criteria: the caused consequences and the days of medical care.

If in the previous regulation, it was considered an infraction to hit a person by fault, with the consequence of causing injury which needed medical care for more than 10 days, in the current regulation, the variant-type of the infraction of bodily injury by fault conditions the retaining of the infraction in the situation of producing consequences specific to the aggravated variant of the hit infraction or other acts of violence only in the case where the deed is committed by a person under the 
influence of alcohol or psychoactive substance or during the unfolding of an activity representing by itself an infraction [1].

The especially high social danger degree of the infraction of bodily injury represents one of the components differentiating it by the infraction of hit or acts of violence. This infraction is an aggravated form of the infraction of hit or other acts of violence stipulated in the dispositions of art. 193 from the Criminal code [2].

\section{Pre-existent conditions}

\section{A. Object of the crime}

a) The special judicial object is represented by the social relationships referring to the protection of each person's body against the deeds bringing damage to the attributes of the person.

In the case of aggravated forms in paragraphs (3) and (4), the infraction has also a secondary judicial object which resides in the social relationships making reference to the observance of the precaution measures for the exercise of a profession or trade, or for carrying out a certain activity [3].

The lawmaker has in view to create a safe environment, individual safety and respect for each member of the society [4].

In the doctrine, it is indicated for good reason that the self-hitting doesn't represent an infraction, unless by doing this, it is injured a special protected interest (for example: a young man mutilates himself in order to escape the military service during war). Likewise, it doesn't represent an infraction the hits or injuries caused by a person on himself/herself trying to suicide. But it doesn't mean that there is a right of the person to dispose of his/her own body, but only that the self-injury actions are not incriminated by the criminal law [5] in so far as they are situated in the individual's personal life and do not bring damage to a social relationship.

b) In the case of these crimes, the material object is represented by the body of the live person upon which the perpetrator acts.

\section{B. Subjects of infraction}

a) The active subject of this infraction can be any person because the law doesn't demand the existence of a special quality of the active subject.

b) The passive subject can be any person. If by the same action or inaction it is produced a bodily injury by fault to two or more persons, then it will be retained a single infraction, in aggravated form [art. 196(4)] [6].

c) As regards the joint enterprise, the deed stipulated in paragraph (1) can be committed through the joint enterprise of co-authorship, if all perpetrators were under the influence of alcohol or of a psychoactive substance or during the unfolding of an infraction activity in itself and they have acted by fault [7].

In the doctrine, it was asserted that the term of "psychotropic substances" means those substances with stimulating substances presenting a risk for the persons' health and which affect the behaviour, consciousness and the mood of the persons consuming them [8]. 
Zazula B.A. (2016)

Bodily injury by fault in the New Romanian Criminal Code

C. The prerequisite situation resides in the fact that the action or inaction is turned against a live person (the foetus and the corpse cannot be victims of this infraction).

In the specialised literature [9], it is highlighted that the infraction of bodily injury represents a variety of the infraction of hitting or other acts of violence, receiving also a special denomination (a personal nomen juris). The difference between the two infractions is given, on one hand, by the number of days of medical care necessary for recovering, and on the other hand by the seriousness of the produced effects. Therefore, the judicial content of the two infractions is the same in both cases.

According to another point of view, the prerequisite situation resides in the existence of a person who before the commission of the deed had a different condition as regards the body and health than the one provoked subsequently by the defendant by fault [10].

\section{Conditions of place and time}

In order to be considered an infraction, the criminal deed committed within the conditions of paragraphs (1) and (2) is not conditioned by place and time. But for the deed committed within the conditions of paragraph (3) to be considered an infraction, it is claimed for it to have been committed at the working place of the perpetrator and during the exercising of a profession or trade or for carrying out a certain activity.

\section{Constituent element}

\section{A. Objective side}

a) The material element of the infraction of bodily injury can be made up of an action or inaction in the situation where the perpetrator, having the legal obligation to hinder the causing of an injury, doesn't fulfil intentionally this obligation, for example: not impeding a bad dog to bite a person, although its master was present at that scene. All these must be committed by fault and to cause to the victim:

- a bodily injury which needed medical care of 90 days at the most;

- an invalidity, traumatic lesions or affecting the health of the person who needed for recovery more than 90 days of medical care; a serious and permanent aesthetic prejudice; abortion, jeopardizing a person's life;

- traumatic lesions or affecting the health condition of two or more persons whose gravity is evaluated by medical care of 90 days at the most;

- traumatic lesions were caused to the victim or it was affected his/her health condition whose gravity is evaluated by medical care of 90 days at the most, the deed representing by itself an infraction.

The deed can be directed against the person's body, but also against mind (for example: it is caused a mental choc to the victim, thus being in need of medical care) [11]. 
Zazula B.A. (2016)

Bodily injury by fault in the New Romanian Criminal Code

As it ensues from the analysis of the text, if the hitting or the violence act committed by fault causes only physical pains or an injury which doesn't require medical care for recovery, then the deed doesn't represent an infraction.

In order to implement the normative version stipulated in paragraph (1), it is necessary to fulfil an alternative condition. Thus, the deed must be committed under the influence of alcohol or of psychoactive substances or during the unfolding of an activity that was in itself an infraction. In any other conditions, causing by fault to the victim an injury which doesn't produce the consequences stipulated in art. 194(1) (bodily injury) and which requires for recovery medical care of up to 90 days is not considered an infraction [12] .

In accordance with the provisions of art. 196(3), it is also about a bodily injury by fault when the commission of the act stipulated at paragraph (2) is represented by the non-observance of legal dispositions or precaution measures for the exercising of a profession or for carrying out an activity.

Hence, the defendant's act to have caused to the victim serious injuries by removing the spleen following a car accident due to the driver's fault, it represents an infraction of bodily injury by fault, in the version stipulated at paragraph (3) of art. 196 from the Criminal code, because it is the effect of not having observed the legal dispositions or precaution measures for exercising the profession [13].

b) The immediate effect, in a first variant, resides in causing traumatic lesions or affecting the person's health condition whose gravity is evaluated at 90 days of medical care at the most.

In the second variant, the immediate effect is represented by one of the consequences:

- an invalidity;

- traumatic lesions or affecting the health condition of a person who needed for recovery more than 90 days of medical care;

- a serious aesthetic and permanent prejudice;

- abortion;

- jeopardizing a person's life.

In the third variant, the immediate effect resides in causing bodily injury to two or more persons. This variant will be considered when each victim has undergone a bodily injury which required medical care for more than 90 days. Therefore, this effect will not be considered if one of the victims needs medical care of 100 days for recovery, and 80 days [14] for the other one.

c) In order to determine the existence of an infraction, it is necessary to establish the causality connection between the action or incriminated inaction and the produced result.

Thus, certain law courts have decided that the person entrusting the vehicle to be driven by a minor, without driving licence and without having experience in 
Zazula B.A. (2016)

Bodily injury by fault in the New Romanian Criminal Code

driving, must and can foresee the harmful effect that can be produced, including injuring the victim.

There is a causality rapport between the action of entrusting a vehicle to be driven by a person without driving licence and the injuring of the victim occurred during a car accident, because the accident wouldn't have happened if it weren't the fault of both perpetrators [15].

\section{B. Subjective side}

a) Subjective element

The infraction of bodily injury by fault can be committed only by fault, with any of its methods (the perpetrator answers for when he/she didn't foresee the result of his/her action, although he/she could and should have foreseen it, but also in the situation where the perpetrator has foreseen the result of his/her action, but hoped, groundless, that it will not occur).

In the case of the aggravated variants stipulated in paragraphs (3), (4) and (5), the fault takes the specific form of the occupational fault which resides in the nonobservance of legal dispositions or precaution measures concerning the exercising of a profession or trade or when carrying out other activities.

In the situation where the perpetrator cannot and is not obliged by a legal disposition to foresee the causing of the dangerous result included in the incrimination norm to be analysed by us, he/she won't answer for criminally (for example: the driver commits a car accident by injuring a person's body with the car picked up right then from the service where it was carried out the periodical technical checking. After performing researches, it was ascertained that the car accident took place because of the steering rod that broke due to a material hole) [16].

b) The motive and purpose do not represent relevance for the existence of the infraction, but possibly for particularising the punishment.

\section{Forms. Sanctions}

\section{A. Forms}

The preparing actions and the attempt are not possible. The infraction is consumed in the moment when the immediate effect takes place [17].

\section{B. Sanctions}

The natural person is punished for the variant specified at art. 196(1) with imprisonment ranging from 3 months to 1 year or with a fine.

According to paragraph (2), in the case of the act that had one of the consequences stipulated at art. 194(1) - medical care for more than 90 days, an invalidity, etc. the punishment for the natural person is with imprisonment ranging from 6 months to 2 years or with a fine. 
Zazula B.A. (2016)

Bodily injury by fault in the New Romanian Criminal Code

In accordance with paragraph (3), when the deed stipulated at paragraph (2) was committed by non-observing the legal dispositions or precaution measures when exercising the profession or trade or when carrying out a certain activity, the punishment is with imprisonment ranging from 6 months to 3 years or with a fine. In compliance with paragraph (4), if the effects stipulated at paragraph (1)-(3) were caused to two or more persons, the special limits of the punishment are increased with a third.

\section{Conclusion}

Defending the life and health of a person is a continuous concern, common to all legal systems. In any social structure, the life and health of a person were protected as primary and absolute values in any society, and the state had the responsibility to create mechanisms ensuring the protection of these social values against unlawful harms.

\section{Notes}

[1] Ristea I. (2014), Drept penal. Partea speciala, vol. I [*Penology. Special part, vol. I], Universul Juridic Publishing House, Bucharest, p. 65

[2] Dungan P., Medeanu T., Pasca V. (2012), Drept penal. Partea speciala, vol. I [*Penology. Special part, vol. I], Universul Juridic Publishing House, Bucharest, p. 70

[3] Antoniu G., Toader T. (coord.), Brutaru V., Danes S., Duvac C., Griga I., Ifrim I., Paraschiv G., Pascu I., Rusu I., Safta M., Tanasescu I., Vasiu I. (2016), Explicatiile noului Cod penal roman, vol. IV [*Explanations for the new Romanian criminal code, vol. IV], Universul Juridic Publishing House, Bucharest, p. 196

[4] Dobrinoiu V., Hotca M.A., Gorunescu M., Dobrinoiu M., Pacu I., Chis I., Paun C., Neagu V., Sinescu M.C. (2014), Noul Cod penal comentat. Partea speciala, Editia a II-a, revazuta si adaugita [*New commented criminal code. Special part. II ${ }^{\text {nd }}$ edition - revised and added-on], Universul Juridic Publishing House, Bucharest, p. 19

[5] Vasiu T., Pavel D., Antoniu G., Lucinescu D., Papadopol V., Ramureanu V. (1975), Codul penal al R.S.R. comentat si adnotat, Partea speciala, vol. I, [*The criminal code of the Socialist Republic of Romania - commented and added-on, Special part, vol. I], Scientific and Encyclopaedic Publishing House, Bucharest, p. 122

[6] Pavaleanu V. (2014), Drept penal special [*Special penology], Universul Juridic Publishing House, Bucharest, p. 48

[7] Ionas A., Magureanu A.F., Dinu C. (2015), Drept penal. Partea speciala [*Penology. Special part], Universul Juridic Publishing House, Bucharest, p. 79

[8] Dungan P. (2011), Analiza continutului infractiunilor contra sigurantei circulatiei pe drumurile publice prin prisma noului Cod penal (II) [*Analysis of the content of infractions against circulation safety on public roads in terms of the new Criminal code (II)], in Law, no. $2 / 2011$, p. 57

[9] Vasiu T. and the collaborators, op. cit, p. 129

[10] Udroiu M. (2014), Drept penal. Partea speciala. Sinteze si grile [*Penology. Special part. Syntheses and multiple-choice tests], C.H. Beck Publishing House, Bucharest, p. 55 
Zazula B.A. (2016)

Bodily injury by fault in the New Romanian Criminal Code

[11] Loghin O., Toader T. (1983), Drept penal. Partea speciala [*Penology. Special part], Didactic and pedagogical Publishing House, Bucharest, p. 131

[12] Dobrinoiu V., Neagu N. (2014), Drept penal. Partea speciala [*Penology. Special part], Universul Juridic Publishing House, Bucharest, p. 56

[13] C.S.J., s. pen., dec. no. 2961/2000 in RDP, no. 4/2002, p. 144

[14] Rusu I., Balan Rusu M. I. (2014), Infractiunile contra sigurantei circulatiei pe drumurile publice in dreptul penal roman [*Infractions against circulation safety on public roads in the Romanian penology], Universul Juridic Publishing House, Bucharest, p. 325326

[15] C. Ap. Cluj, dec. pen., no. 688/R/1999

[16] Ionas A., Magureanu A.F., Dinu C., op. cit., p.

[17] Vladoiu N.M. (2014), Drept penal roman. Partea speciala [*Romanian penology. Special part], Universul Juridic Publishing House, Bucharest, p. 47

\section{Bibliography}

Treaties, courses, monographs

1. Antoniu G., Toader T. (coord.), Brutaru V., Danes S., Duvac C., Griga I., Ifrim I., Paraschiv G., Pascu I., Rusu I., Safta M., Tanasescu I., Vasiu I. (2016), Explicatiile noului Cod penal roman, vol. IV [*Explanations for the new Romanian criminal code, vol. IV], Universul Juridic Publishing House, Bucharest

2. Dobrinoiu V., Hotca M.A., Gorunescu M., Dobrinoiu M., Pacu I., Chis I., Paun C., Neagu V., Sinescu M.C. (2014), Noul Cod penal comentat. Partea speciala, Editia a II-a, revazuta si adaugita [*New commented criminal code. Special part. $I^{\text {nd }}$ edition - revised and added-on], Universul Juridic Publishing House, Bucharest

3. Dobrinoiu V., Neagu N. (2014), Drept penal. Partea speciala [*Penology. Special part], Universul Juridic Publishing House, Bucharest

4. Dungan P., Medeanu T., Pasca V. (2012), Drept penal. Partea speciala, vol. I [*Penology. Special part, vol. I], Universul Juridic Publishing House, Bucharest

5. Ionas A., Magureanu A.F., Dinu C. (2015), Drept penal. Partea speciala [*Penology. Special part], Universul Juridic Publishing House, Bucharest

6. Loghin O., Toader T. (1983), Drept penal. Partea speciala [*Penology. Special part], Didactic and pedagogical Publishing House, Bucharest

7. Pavaleanu V. (2014), Drept penal special [*Special penology], Universul Juridic Publishing House, Bucharest

8. Ristea I. (2014), Drept penal. Partea speciala, vol. I [*Penology. Special part, vol. I], Universul Juridic Publishing House, Bucharest

9. Rusu I., Balan Rusu M. I. (2014), Infractiunile contra sigurantei circulatiei pe drumurile publice in dreptul penal roman [*Infractions against circulation safety on public roads in the Romanian penology], Universul Juridic Publishing House, Bucharest 


\section{JOURNAL OF LEGAL STUDIES}

"Vasile Goldiș" Western University of Arad

Zazula B.A. (2016)

Bodily injury by fault in the New Romanian Criminal Code

10. Udroiu M. (2014), Drept penal. Partea speciala. Sinteze si grile [*Penology. Special part. Syntheses and multiple-choice tests], C.H. Beck Publishing House, Bucharest

11. Vasiu T., Pavel D., Antoniu G., Lucinescu D., Papadopol V., Ramureanu V. (1975), Codul penal al R.S.R. comentat si adnotat, Partea speciala, vol. I, [*The criminal code of the Socialist Republic of Romania - commented and added-on, Special part, vol. I], Scientific and Encyclopaedic Publishing House, Bucharest

12. Vladoiu N.M. (2014), Drept penal roman. Partea speciala [*Romanian penology. Special part], Universul Juridic Publishing House, Bucharest

\section{Specialisation magazines}

13. Dungan P. (2011), Analiza continutului infractiunilor contra sigurantei circulatiei pe drumurile publice prin prisma noului Cod penal (II) [*Analysis of the content of infractions against circulation safety on public roads in terms of the new Criminal code (II)], in Law no. 2/2011 